\title{
The Fourth Pillar and the U.K.: Flexibility, Risk and the Deinstitutionalization of the Life Course
}

\author{
Patrick John Ring \\ Division of Risk, Associate, The Centre for Risk and Governance, Caledonian Business School, Glasgow \\ Caledonian University, City Campus, Cowcaddens Road, Glasgow G4 0BA, U.K. \\ E-mail: p.ring@gcal.ac.uk
}

This paper critically examines the concept of flexibility within the context of demographic ageing and the fourth pillar approach. Using the U.K. as an example, it addresses some of the key strands of policy debate and highlights the importance of the concept of choice. By placing the discussion in the context of the theoretical debate surrounding risk and the deinstitutionalization of the life course, it suggests that policy solutions related to demographic ageing which address the concept of flexibility need to look beyond later years to address the whole of the life course.

The Geneva Papers (2005) 30, 638-655. doi:10.1057/palgrave.gpp.2510054

Keywords: retirement; risk; flexibility; fourth pillar; deinstitutionalization

\section{Introduction}

The relevance of the fourth pillar, that is the labour income of workers past early retirement or pension age, increasingly has come to be seen as a key element of financing pensions in the face of demographic ageing. ${ }^{1}$ The importance of developing a fourth pillar strand to pension provision has been characterized by the U.K. Government as follows:

Many older people retire early even though they find work rewarding. Given greater flexibility, they would prefer to stay in work. Longer working can dramatically reduce the amount of saving needed for retirement - it gives people more time to save and means that their savings do not have to last as long. ${ }^{2}$

Its aim is to encourage what the Government, and others, have referred to as a regime of "flexible retirement". 3

Flexibility has been a key concept in the fourth pillar approach. ${ }^{4}$ This paper critically examines the concept of flexibility within the context of demographic ageing and the fourth pillar approach, using the U.K. as a case study. Given the relatively

\footnotetext{
${ }^{1}$ Dunnewijk (2002).

${ }^{2}$ DWP (2002, p. 94).

${ }^{3}$ DWP (2002); Bone and Mercer (2000).

${ }^{4}$ Kessler (1988); Dunnewijk (2002).
} 
poor levels of state pension provision in the U.K., ${ }^{5}$ and both the importance of, and difficulties currently experienced with, private pension provision, the U.K. provides an interesting comparator for other European countries coping with the issue of demographic ageing.

The paper begins by outlining the issues raised by demographic ageing and some of the key strands of policy debate that accompany this phenomenon. It then goes on to examine the concept of flexibility and suggests that the concept of choice is also important. There follows an examination of the theoretical debate surrounding risk and the deinstitutionalization of the life course, which in turn suggests it is important, in discussing retirement and the relevance of the fourth pillar, not to limit notions of flexibility and choice to the later years of life. The importance of such an outlook is underlined through critical examination of current U.K. policy.

\section{Background: demographic ageing}

It has often been said that developed countries have to cope with a "demographic time bomb" as a result of increasing longevity. Of course, it is not just that more people are living longer and, as they get older, making greater claims to state provision. The size of younger generations as a percentage of the population as a whole, the support ratio, is also decreasing. The European Commission has estimated that by 2015 the working population of most of the EU's Member States will be in decline, ${ }^{6}$ and that between 2000 and 2050, the EU's support ratio will fall from 4:1 to 2:1, identifying this issue as one of "demographic ageing". 7 In the U.K., the life expectancy of both men and women has increased significantly and will continue to increase over the next 50 years. ${ }^{8}$ At the same time, the U.K.'s support ratio continues to fall. ${ }^{9}$ It is certainly true to say, therefore, that the U.K. is experiencing demographic ageing.

\section{Strands of the policy debate}

While the fact of demographic ageing is clear, its implications are broader and more arguable. Nevertheless, three key strands in the debate can be identified.

\section{Squeezing public, expanding private provision}

The most obvious, and well-publicized, strand of the debate concerns the increasing cost of state pension provision resulting from the increase in the size of the "retired" population. It is estimated that for a majority of the EU-15 countries, it will add

\footnotetext{
${ }^{5}$ Pensions Commission (2004, p. 58).

${ }^{6}$ EU Commission (1999).

${ }^{7}$ EU Commission $(1999,2002)$.

${ }^{8}$ DWP (2002, p. 16).

${ }^{9}$ OECD (2004, p. 37).
} 
640

approximately 3-5 per cent of GDP to pension expenditure. ${ }^{10}$ This challenge has led many of those countries to contemplate reforming pension systems as a means of securing their long-term fiscal sustainability.

\section{Position in the U.K.}

As a result of curtailing real levels of state pension entitlements, ${ }^{11}$ the U.K. has one of the lowest replacement rates for state benefits in the OECD. ${ }^{12}$ Predictions suggest that spending on state pension, as a share of national income, is likely to remain stable, if not decrease, in the period to $2050 .^{13}$

Of course, retrenchment of state provision creates challenges for those faced with making up any shortfall through greater private-funded provision. Consumers, for their own financial security as well as for the sake of broader societal security, need to be able to navigate their way through potentially complex financial markets. As a consequence, their success in doing so also becomes a matter of concern for Government as well as for the individuals themselves.

Yet, these challenges arise in the U.K. at a time when its private pensions landscape is not as healthy as had previously been thought. Many employers appear to be taking the view, as Government did two decades before, that their financial commitments to pension provision in the face of demographic ageing are unsustainable. As a result, there has been a shift from final salary "promises" to money purchase provision, and it appears that over 70 per cent of final salary schemes may now be closed to new entrants, ${ }^{14}$ with active membership of private defined benefit schemes having fallen by perhaps as much as 60 per cent since $1995 .{ }^{15}$ This "seismic shift in pension provision" 16 is compounded by employers taking the opportunity to reduce their level of pension contributions to alternative arrangements. ${ }^{17}$

This has had the effect of reducing employers' future liabilities, while shifting greater risk onto their employees. At the same time, savers have seen markets and annuity rates tumble, and with them the value of their pensions savings. ${ }^{18}$ A series of scandals has left the U.K.'s financial services sector tarnished, disillusioning many potential pension savers who, it is apparent, are only now fully appreciating the extent of the state's and employers" "stepping back" from pension provision. The result is an alleged "savings gap" between what people should be saving for retirement, and what they are saving, of anything between $£ 16$ and $£ 66$ billion. ${ }^{19}$

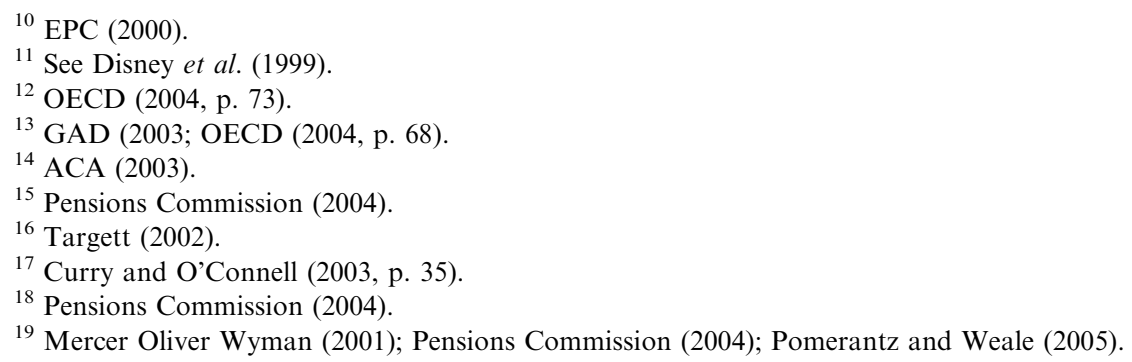




\section{The shift to early retirement}

As already indicated, demographic ageing brings not only the challenge of securing adequate retirement provision for a growing elderly population but also the prospect of a shrinking workforce. At the same time, over the past 30 years many countries have experienced the phenomenon of the "early retirement" of workers. ${ }^{20}$

\section{Position in the U.K.}

In the U.K., around three million people between fifty and state pension age are not working. ${ }^{21}$ The trend, particularly amongst men, towards ever-earlier withdrawal from the work force has been regarded as particularly worrying. ${ }^{22}$ Between 1976 and 2000, those aged 50 to 64 and not in work or looking for work increased from 11 per cent to 27 per cent of the labour force. ${ }^{23}$ Despite evidence that this trend may be reversing slightly, ${ }^{24}$ it has been estimated that non-employment of those aged over 50 could cost the U.K. economy up to $£ 30$ billion annually. ${ }^{25}$

Herbertsson and Orszag $^{26}$ point out that, even though the cost of falling employment rates in the over-50s may be declining compared to the mid-1980s, if current rates remain constant then the future effect of an ageing population will be to increase the public cost of early retirement dramatically simply because more workers will be older. As a result, there has been greater emphasis upon improving the participation rates of older workers. ${ }^{27}$ In the U.K., the Government has introduced its Age-Positive campaign to promote the benefits of an age diverse workforce to employers, as well as schemes to improve the employability of older workers. ${ }^{28}$ More recently, it announced a shake-up of incapacity provision from 2008 to encourage more of the long-term sick back into work. ${ }^{29}$

\section{Demographic ageing as an issue of equality and opportunity}

With an ageing population comes a greater emphasis upon the needs and desires of those older persons now forming an ever-larger percentage of the population. The EU has identified the need for "active ageing policies and practices" that include "being active after retirement and engaging in capacity enhancing and health sustaining activities". ${ }^{30}$ As Taylor puts it, "A new consensus is emerging around the notion of active or productive ageing". ${ }^{31}$

\footnotetext{
20 Taylor (2002).

${ }^{21}$ PIU (2000, p. 13); NAO (2004).

22 PIU (2000); Taylor (2002, p. 5).

${ }^{23}$ Phillipson (2002, p. 4); Anon (2004).

24 Taylor (2002, p. 5); Anon (2004).

${ }^{25}$ PIU (2000); OECD (2004).

${ }^{26}$ Herbertsson and Orszag (2003).

${ }^{27}$ EPC (2000, p. 9).

${ }^{28}$ OECD (2004); NAO (2004).

${ }^{29}$ Hall (2005).

${ }^{30}$ EU Commission (2002, p. 6).

31 Taylor (2002, p. 1).
} 
642

Position in the U.K.

For the purposes of this discussion, there are two key themes in this strand of the demographic ageing debate in the U.K.. Firstly, there has been increasing recognition of the issue of age discrimination. ${ }^{32}$ Evidence suggests that many older people feel that they are either excluded from the workplace or forced to leave earlier than they would have wanted, solely on the basis of age. ${ }^{33}$ Despite the Government's voluntary 1999 Code of Practice on Age Diversity in Employment, employers still appear to discriminate on the basis of age. ${ }^{34}$ While implementation of the EU's Directive on Equal Treatment in Employment and Occupation will also introduce a statutory prohibition against age discrimination, statutory measures can be limited in their effectiveness. $^{35}$

The second theme relates to the ability of individuals to "flexibly" manage their transition from work to retirement. Here, it is argued that by creating the policy framework within which those over 50 who currently leave employment early find it easier to remain in, or re-enter, the workforce through having or acquiring the skills employers seek; by reforming the pension system so that instead of moving over a "cliff-edge" from work to retirement, individuals can develop their own appropriate "pathways" from work to retirement; and by encouraging employers to adopt employment practices that facilitate both of the above, the quality of later life will be improved for individuals, who will be in a better position to positively manage their transition from "full" employment to "full" retirement.

\section{Flexibility: a focal point for debate}

The notion of flexibility is significant, both in the U.K. and elsewhere, in discussions concerning the trend towards early retirement and, more generally, demographic ageing. It is a significant element in any discussion of the fourth pillar, and an issue often highlighted in relation to the U.K. debate on demographic ageing. ${ }^{36}$

The U.K. Government has defined flexible retirement as "the term often used to describe a move from full-time to part-time work, or to less responsible positions, towards the end of a persons career. It is an alternative to the cliff-edge that many people face when moving from full-time, demanding work to complete retirement". 37 This fits with The Geneva Association's view that the fourth pillar of retirement provision represents "the future need for a flexible extension of work-life, mainly on a part-time basis, in order to supplement income from the three existing pillars". 38

It is important to distinguish here between the fact of moving from full-time to parttime work in later life, and the means by which, and exactly for whom, this comes to be

${ }^{32}$ PIU (2000); Hirsch (2003, p. 15); OECD (2004).

${ }^{33}$ Compton-Edwards (2001); OECD (2004).

${ }^{34}$ DWP (2002, p. 96); Taylor and Walker (2003).

${ }^{35}$ Taylor (2002).

${ }^{36}$ PIU (2000); DWP (2002); OECD (2004).

${ }^{37}$ DWP (2002, p. 105).

${ }^{38}$ The Geneva Association (2002). 
regarded as "flexible". Meadows points out that "the debate on labour market flexibility is confused by the fact that different people mean different things by the term". 39 Flexibility can be considered at the level of the economy, the firm or the individual. It can also be discussed in terms of hours, pay, functionality or employee numbers.

Importantly, flexibility is a contested concept. An example of this in the U.K. has been the debate over whether in the future to prevent employers from setting mandatory retirement ages. On the one hand, this would open up more flexibility for employees in their retirement decisions (flexible retirement), but at the same time would reduce the flexibility of employers to terminate the employment relationship (flexible employment practices). While it has been argued that restrictions on mandatory retirement by employers would have a small but positive effect on growth and output, ${ }^{40}$ it appears that, for the present, the Government has decided that employers' ability to compulsorily retire their employees should, in practical terms, remain. ${ }^{41}$

\section{Flexibility and the employment relationship}

The foregoing discussion emphasizes the importance of the employment relationship to understanding the flexible retirement debate. Potentially, any labour market or retirement reform that purports to offer flexibility may do so in a way that is regarded as providing more flexibility for one party to the employment relationship to a greater extent than, or to the detriment of, the other.

U.K. employers are already regarded as having a great deal of flexibility in the employment relationship. ${ }^{42}$ Nevertheless, when the Employer's Forum on Age discusses the need to facilitate flexible retirement as "a means of managing capacity and skills within an organization", 43 and the DWP talks of the flexibility required to enable the modification of the structure of employees' pension benefits, ${ }^{44}$ the increased flexibility sought relates to the behaviour of employers. Recent research underlines the importance to employers of being able to control the retirement process. ${ }^{45}$ The shift from defined benefit to defined contribution benefits as well as the trend of some U.K. employers (including the Government) towards increasing scheme retirement ages, in both cases generally reducing costs for employers and benefits for employees, illustrate employer flexibility that results in a potential reduction in flexibility for employees.

On the other hand, most individuals want choice in relation to the nature and timing of their retirement, ${ }^{46}$ and some employers are also convinced of the importance to their business of creating more choice for employees in relation to the age at which they retire, the length of time they take to retire or the nature of the work they carry

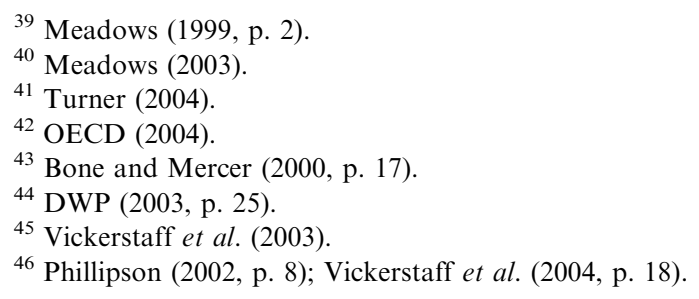


out in the period leading to retirement. ${ }^{47}$ Nevertheless, Hirsch points out that "most of the evidence shows that employers are at best "permissive" of worker requests to move from their career jobs, rather than actively promoting such opportunities". 48 It appears that while some employers recognize that employee flexibility is important, this may often be restricted to instances where it does not curtail the potential flexibility of employers. A recent survey suggested that while nearly 40 per cent of businesses recognized the benefits of flexible working, more than 60 per cent said they were "unlikely to" or "definitely not" going to operate such a policy. ${ }^{49}$

\section{Choice and constraints}

Research indicates that the key determinant of quality of life in retirement is the ability to exercise choice over the decision to retire. ${ }^{50}$ Therefore, rather than discuss flexible retirement practices, it may be more useful to focus upon the extent to which individuals are able to choose and control when and how they reach "full" retirement.

It is not just the employment relationship that is relevant here. A range of factors such as finances, health, family circumstances and attitude to work interact with the employment relationship to produce specific retirement outcomes for particular individuals. ${ }^{51}$ The cultural, social and economic capital that individuals possess, along with their particular preferences, interact within the setting of the employment relationship. As Vickerstaff et al. put it, "The organisation provides the stage on which individual scenarios are played out... In reality... a combination of personal factors and organisational practices serve to produce both opportunities and threats to individual choice". 52

While it is clear that individuals want choice and control in relation to their retirement pathway, it is also clear that the better off, better educated, more skilled and those more knowledgeable about financial services are better able to achieve this, negotiating any structural constraints they face. ${ }^{53}$ The better off have the financial security to enable them to more confidently plan to retire early if they so desire. ${ }^{54}$ The more skilled and educated are more likely to be in a position to negotiate with their employer (or, in the case of the self-employed, their clients) the kind of part-time work or consultancy arrangement that will allow them, if they wish, to effect a gradual, but economically secure, transition from work to retirement. Those more knowledgeable about financial services will be better able to plan ahead, negotiating the complexity of the financial services sector to make the choices they wish in relation to their retirement outcomes. ${ }^{55}$

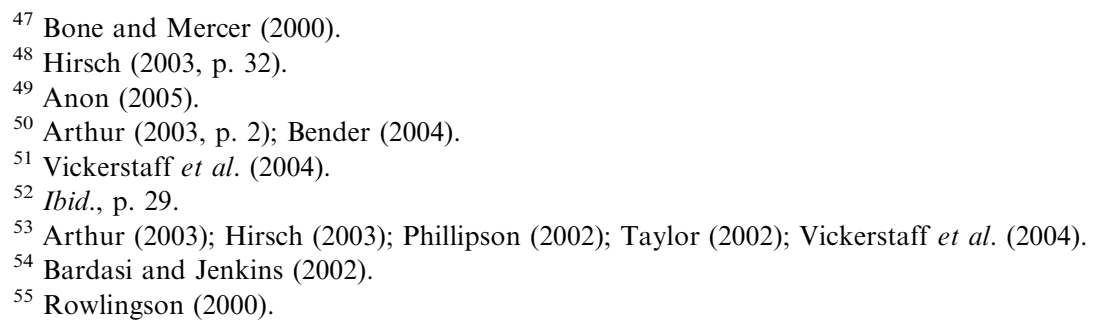




\section{Setting policy in context}

The analysis provided so far has underlined the fact that any discussion of the fourth pillar of pension provision and the concept of flexibility in retirement must be placed in a broader context, involving both the contestation of the notion of flexibility and the issue of individual choice. Further justification for this approach can be found in a consideration of the theoretical debate surrounding demographic ageing, and it is to that debate that this paper now turns.

\section{Risk society and the deinstitutionalization of the life course}

It has been suggested that "the invention and generalization of retirement pensions... decisively helped to construct and consolidate [a] 'tripartition' of the life course", ${ }^{56}$ that is, into periods of education (preparation for work), work itself and retirement (cessation of work). Education qualified an individual for work, and work formed the basis of qualifying for retirement provision. In this process, state pension age acted to clearly, and sharply, define the shift from work to retirement, standardizing and creating predictability in expectations, marking the boundary line which, once crossed, moved the individual from the world of work to the world of retirement, the latter often underpinned by the welfare state.

More recently, some trace a decline in the centrality of this life-course model for making sense of the retirement process. ${ }^{57}$ Experience suggests that, in many countries, the traditional social framework upon which retirement provision has been based is changing. ${ }^{58}$ "Normal retirement age" and "state pension age" have become less relevant as signifiers of complete withdrawal from employment and the work environment. As Guillemard puts it, "public retirement systems are no longer the central means for regulating definitive withdrawal from the labour force". 59 In the U.K., only 12 per cent of people now cease work at state pension age. ${ }^{60}$ There has been a "deinstitutionalization" of the life course. The moment at which a working life ends has become more open, uncertain and unpredictable. There is a greater variety of paths through this later part of the life course. ${ }^{61}$ This creates greater opportunities for flexibility and choice but also means individuals are less able to anticipate or predict their trajectory to retirement. At the same time, this also makes it more difficult for the state, through the traditional institutions of welfare, to anticipate and/or shelter individuals from the risk and potential insecurity that inheres in such flexibility.

\footnotetext{
${ }^{56}$ Guillemard (2001, p. 3).

${ }^{57}$ See, for example, Guillemard (1997).

${ }^{58}$ Watson Wyatt (2005).

${ }^{59}$ Guillemard (1997, p. 446).

${ }^{60}$ Pensions Commission (2004).

${ }^{61}$ Phillipson (2002).
} 


\section{Moving towards a risk society}

.... Entry into risk society occurs at the moment when the hazards which are now decided and consequently produced by society undermine and/or cancel the established safety systems of the provident state's existing risk calculations. ${ }^{62}$

In relation to financial well being, the risk society thesis questions both the certainty and calculability of risk via insurance, and the place of the state as the guarantor of welfare to the greatest number. As industrial society moves towards becoming a risk society, the "hazards and problems produced by [this process]... exceed the bases of societal conceptions of security". ${ }^{63}$ Thus, Giddens argues that the welfare state "today creates almost as many problems as it solves". ${ }^{64}$

If deinstitutionalization, with its shift of focus to the active role of individuals in shaping their own retirement pathway, is a reflection of the move towards a risk society, then the risk society thesis implies that individuals have to play a greater, or at least different, role in coping with the risks they now face in the new, deinstitutionalized, progression from work to retirement. As Beck puts it, the "disenchantment of collective and group specific sources of meaning of the culture of industrial society... leads to all the work of definition being expected of or imposed on individuals themselves". 65 Giddens conceptualizes this as a "new individualism" in which "we need more actively to accept responsibility for the consequences of what we do". 66

It is unsurprising, therefore, when Phillipson, discussing the transformation of the life course, suggests that there is "more uncertainty, more possibilities and more potential on the one hand, but less intervention in respect of social and public policy on the other". ${ }^{67}$ The transition experienced in later life is "one in which selfdevelopment is a more individualised (and deinstitutionalised) process". ${ }^{68}$

\section{Crisis of security}

Alongside this greater emphasis on role of individuals in "constructing" their own retirement path, Guillemard suggests there is crisis in the life plans of individuals. She argues:

Not provided with clear views of new trajectories, people feel how socially insecure their future is. Faced with deep uncertainty, individuals cannot foresee their future and make plans for it. ${ }^{69}$

\footnotetext{
${ }^{62}$ Beck (1996, p. 31).

${ }^{63}$ Beck (1996, p. 29).

${ }^{64}$ Giddens (1998, p. 16).

${ }^{65}$ Beck (1996, p. 29).

${ }^{66}$ Giddens (1998, p. 36, 37).

${ }^{67}$ Phillipson (2002, p. 26).

${ }^{68}$ Ibid., p. 21.

${ }^{69}$ Guillemard (2001, p. 3).
} 
Providing, as it did, some level of security against the risks arising out of a fixed and foreseeable life course, much of the state's welfare provision for later life now appears anachronistic in the face of a wide array of unpredictable routes from work into retirement - as Phillipson puts it, the welfare state has been "residualized".70 However, the removal of the centrality of state provision does not remove the centrality of risk.

While risk is inherent in the process of making provision for retirement, it is also clear that, in the U.K., the locus of responsibility for such risks is moving, away from the state and employers, and more clearly towards individuals. ${ }^{71}$ This may well be emancipatory for some, but it creates real challenges for many more. Guillemard argues that the "major objective is... not to guarantee coverage for risks.... Instead, it should make life-course trajectories, now individualized and uncertain, secure". ${ }^{72}$

\section{Critical analysis of U.K. policy}

The residualization of the state, flexibility and the management of risk

Individuals, as they move towards retirement, face an array of complexity and uncertainty that has hitherto been inadequately recognized. ${ }^{73}$ At the same time, the risk society thesis suggests the state is now less able to provide individuals with guarantees and protection in the face of such uncertainties.

The U.K. Government has therefore set out to "make flexible retirement easier" by aiming to "help people choose how they plan for retirement, how much they save and how long they keep working". 74 It has adopted an "informed choice" strategy. This involves increasing financial awareness and capability to ensure individuals are better informed about their retirement options, their opportunities for flexible working and the implications of their behaviour on their financial well being in retirement. ${ }^{75}$ It includes providing improved pension forecasts to individual scheme members, ${ }^{76}$ simplifying the taxation regime relating to pensions, ${ }^{77}$ and doing much more in schools and the labour market to increase awareness and education in financial services. ${ }^{78}$

However, when a significant number is uninterested in learning, or unable to learn, about savings and pensions, ${ }^{79}$ and many ignore their financial statements, ${ }^{80}$ there must be doubt about the extent to which individuals will make use of this information. ${ }^{81}$

\footnotetext{
${ }^{70}$ Phillipson (1999, p. 325).

${ }^{71}$ Arthur (2003).

72 Guillemard (2001, p. 6).

${ }^{73}$ Phillipson (2002).

${ }^{74}$ DWP (2002, p. v).

75 DWP (2004).

${ }^{76}$ DWP (2003, 2004).

${ }^{77}$ Inland Revenue, HM Treasury (2003).

78 DWP (2004).

${ }^{79}$ Vickerstaff et al. (2004).

${ }^{80}$ Boles (2000).

81 NCC (2003).
} 
648

The FSA accepts that "Most of the population find long-run financial planning "incomprehensible and deeply dull", ${ }^{82}$ Equally, research suggests "it is not enough to provide information on demand. People may not demand it soon enough to be able to make sensible plans and decisions about their financial futures". ${ }^{83}$ Yet, even if better financial education is a solution, it is not clear there will be sufficient funds available for the Government's financial education initiatives. ${ }^{84}$

Notwithstanding these problems, it may nevertheless be argued that greater flexibility will offer many the possibility of acting positively to overcome the risk and uncertainty in state and private provision, and of taking steps to secure their own future in retirement. However, the evidence to date on the extent of retirement saving suggests that this may not be happening to the extent the Government hoped. ${ }^{85}$ One explanation is what Taylor-Gooby refers to as "timid prosperity". ${ }^{86} \mathrm{He}$ argues that many feel insecure and unable to take action because of the potential consequences of making wrong savings or investment decisions, particularly in the context of what appears to be an increasingly uncertain private pensions sector. The residualization of the welfare state has only heightened fearfulness.

The Government's radical overhaul to simplify pension provision in the U.K. may not greatly improve the position. It has, for example, introduced measures that, for the first time, will enable the taking of pension benefits while remaining in the job to which those benefits relate. It has been acknowledged that this is a significant change, creating "further flexibility" in the retirement process. ${ }^{87}$ Nevertheless, the availability of this facility will depend upon both pension schemes and employers adopting this more flexible approach. Given the reticence of employers to cede any control of the retirement process, and their influence over the control of occupational pension schemes, ${ }^{88}$ the extent to which the U.K.'s simplification measures will actually contribute to the aims of the fourth pillar approach and provide more choice for individuals remains open to question.

Overall, despite Government initiatives, there are many in the U.K. who may not, even in the long term, be able to make choices and exercise flexibility in a way that enables then to cope adequately with the risk and uncertainty that the deinstitutionalization of the life course has brought. That failure to cope may condemn them to benefits at among the lowest levels in the OECD. ${ }^{89}$

\section{Economic growth and flexibility}

As already indicated, the U.K. Government is concerned about the economic costs of lower labour market participation rates among the over-50s. ${ }^{90}$ Yet, if there is a

\footnotetext{
${ }^{82}$ HL Select Committee on Economic Affairs (2003, p. 42).

${ }^{83}$ Vickerstaff et al. (2004, p. 37).

${ }^{84}$ Skypala (2003); FSA (2003, p. 14).

${ }^{85}$ Mercer Oliver Wyman (2001); Pensions Commission (2004).

${ }^{86}$ Taylor-Gooby (2000).

${ }^{87}$ Hewitt and Woodrow (2003, p. 4).

${ }^{88}$ Cocco and Volpin (2005).

${ }^{89}$ OECD (2004, p. 68).

${ }^{90}$ PIU (2000).
} 
significant loss to the economy and productive ouput as a result of older workers having left the workforce, it seems somewhat surprising that employers have failed to take advantage of this unused resource. It may be argued that, given the comparatively high percentage of older men employed in manual occupations in the U.K., ${ }^{91}$ it is far from clear that these are the workers whose skills would be those most in demand by employers and therefore the ones able to take advantage of "flexible" retirement options. ${ }^{92}$ Arguably, it is those with greater skills (and for whom a shortage exists) who are more likely to be able to afford and negotiate early retirement; while less skillful workers may be the very ones employers would wish to get rid of. Ironically, the U.K. Government's increase in the earliest age at which early retirement is allowed may well have the effect of forcing employers to retain less productive workers for longer.

For those who do retire early, the Government notes that "given greater flexibility, they would prefer to stay in work longer". ${ }^{93}$ The participation rates of over-50s in the U.K. are mixed when compared to, and in some cases significantly lower than, average OECD levels. ${ }^{94}$ While more can be done to encourage a greater return to work, ${ }^{95}$ it is suggested that, for policy responses to be more effective, as much emphasis needs to be placed upon responding to structural social and economic issues as on individual support programmes to "re-incentivise" older workers. ${ }^{96}$ Research indicates "that 1.2 million incapacity benefit claimants would be in work if the U.K. economy were as strong in former industrial areas as it is in the Home Counties". 97 And while the Government's recent proposal to reform incapacity benefit, providing greater help to find work, is a positive step, ${ }^{98}$ effectively "punishing" those who do not take sufficient advantage of that help by reducing their benefit level, it overlooks the fact that money is not the principal determinant of the decision to leave work. ${ }^{99}$

By placing "individualizing" policies at the heart of its approach, the Government risks underplaying the broader structural pressures that form part of the explanation for the low participation rates for over-50s and the rise in successful incapacity benefit claims. As the OECD puts it, if any reforms are to be successful, "they need to operate in a broader perspective". 100

It may be also suggested that, given the increasing prevalence of part-time work, short-term contracts, sub-contracting and job changes in the course of a working life, many in today's working population are already used to "flexibility" in employment, although often not of their own choice. ${ }^{101}$ While once more underlining the polysemic

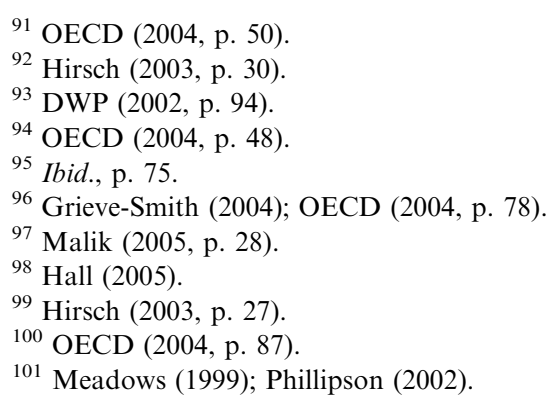


nature of the term "flexibility", it suggests greater flexibility of this nature is not the way to encourage higher participation rates in later life.

It also suggests that in dealing with the phenomenon of "early retirement", as well as better appreciating the organizations' constraints of the employment relationship, there needs to be a more fundamental examination of individuals' skills and employment needs throughout their lives. As Hirsch puts it, "only long-term policies to improve quality of work and of people's skills - especially their adaptation skills rather than measures directed specifically at older people" can start to address the extent of choice and control that people have in their exit from work. ${ }^{102}$

If early retirement results in significant loss in economic growth, then it is not clear that greater flexibility, at least not as it is currently given effect in the U.K., will provide an adequate solution.

\section{Equality and opportunity}

In the U.K., older employees and potential employees still experience discrimination $^{103}$ in spite of the existence of the Government's Code of Practice on Age Diversity in Employment. ${ }^{104}$ However, if there is concern about equality and opportunity for the over-50s, then it is important to appreciate the clear links between income in later life and work-life history. ${ }^{105}$ Those with low incomes in their working life have little savings and little flexibility in their response to losing or leaving employment in later life; hence, a dependence on benefits or on lower paid or casual work. ${ }^{106}$

The implication is that any focus on equality and opportunity must emphasize lifelong policies that truly encourage equality of opportunity to acquire new and transferable skills throughout life (not just for the over-50s) in order to create a workforce better able to make provision for themselves throughout their lifetime. If we really are moving towards a "risk society", then it is only through providing the support that empowers individuals throughout their lives that one is likely to see the "new individualism" mentioned by Giddens. ${ }^{107}$

In determining that support, there needs to be a clear message about the role of employers in the U.K. as providers of pension provision, ${ }^{108}$ as well as their role in facilitating choice for employees. Equally, Government must do more to integrate the position of older people into their general policy agenda. For example, and as already pointed out, research indicates that many older people choose to leave work due to health issues, caring responsibilities or family obligations. ${ }^{109}$ Yet, the Government's policies on work-life balance appear to be focused more on parents than on the population as a whole. ${ }^{110}$

\footnotetext{
${ }^{102}$ Hirsch (2003, p. 27).

${ }^{103}$ PIU (2000, p. 38).

104 Compton-Edwards (2001).

105 Bardasi and Jenkins (2002).

106 Vickerstaff et al. (2004, p. 31).

${ }^{107}$ Giddens (1998, p. 36).

${ }^{108}$ Employer Task Force on Pensions (2004).

${ }^{109}$ Hirsch (2003, p. 18).

110 Ibid., p. 17.
} 


\section{Conclusion}

The fourth pillar debate highlights the importance of flexibility in the retirement process. This discussion has argued that greater attention needs to be given to the issue of flexibility - or more properly choice - throughout the life course. This is acknowledged by those who advocate the fourth pillar approach. As Reday-Mulvey notes, such a conception of flexible retirement "also marries up with many of the changes and needs that are specific to our contemporary service economies (the increasingly flexible nature of employment and of the life-cycle)". ${ }^{111}$ Nevertheless, the example of the U.K. shows how many more fundamental issues can become veiled behind the detail of policy discussion.

This paper has used the debate in the U.K. to highlight the need to question what is meant by flexibility in the retirement process. The answer is not obvious, and the way in which flexibility is understood remains a site of debate and contestation inhabited by (at least) the two sides to the employment relationship. Calls for greater flexibility in retirement, and measures aimed at providing such flexibility, need to be placed in this context.

It has also suggested that another way to approach the discussion is by focusing upon the retirement choices available to individuals as they reach later stages of life. Here, the U.K. Government notes that most over-50s who leave work do not do so voluntarily. ${ }^{112}$ Its focus has therefore been on encouraging more over-50s back to work, including specific programmes for these affected groups, as well as attempts to reduce age discrimination. It is also raising the minimum age at which an early retirement pension can be paid. There are a number of points that can be made about this in relation to the issue of choice.

Firstly, while the Government aims to encourage the over-50s back to work, ${ }^{113}$ it is clear that current policy also has a more coercive element for those who do not heed this "encouragement". It may be suggested that the primary driver here is not choice for individuals, but the economic choices Government has already made about Government spending, welfare provision and the future role of the state. As Hirsch notes, while the Government's approach "can be presented as improving opportunities for older people, it can also appear coercive, by making it harder for people to leave work early where they wish to do so". ${ }^{114}$ It is therefore somewhat disingenuous to continually present such reforms in the context of greater choice and flexibility for individuals.

Secondly, if Government wants individuals to have more choice in moving to retirement, then it will need to exert greater influence over the social, economic and organizational structures which form the context within which retirement decisions are made. Even with the introduction of anti-discrimination legislation, there still appears to be much more work to be done in this area if retirement decisions are to be more in the hands of employees.

\footnotetext{
111 Reday-Mulvey (2002, p. 4).

112 PIU (2000, p. 22).

113 Ibid., p. 6.

${ }^{114}$ Hirsch (2003, p. 8).
} 
652

When considering individualized approaches to policy then, notwithstanding clear efforts the U.K. Government has made to improve the position of the over-50s, ${ }^{115}$ greater emphasis needs to be placed upon policies that influence life history and skills across all age groups. ${ }^{116}$ For the over-50s who lack pension provision, this is likely in some measure to be a reflection of their lower income in earlier years, or lack of access to employment with an employer offering pension provision. As already discussed, lower income may also indicate a lower level of skills, which in turn will affect the ability of an employee to exert influence upon an employer in shaping their own retirement decisions and their ability to find other employment, as well as their ability to plan ahead and make sense of the choices available in today's financial services markets. This suggests a greater emphasis on "long-term policies to improve the quality of work and of people's skills - especially their adaptation skills - rather than measures directed specifically at older people". ${ }^{117}$

This last argument is also supported by the theoretical discussion in this paper. If we are truly moving towards a "risk society", in which the deinstitutionalization of the life course is taking place, then individuals have to play a greater role in coping with the risks and hazards they face. While uncertainty and unpredictability can also bring with them greater choice and possibilities, individuals need to be able to exploit such possibilities. Government policies, therefore, must emphasize the importance of developing people, their skills and potential, throughout their lives, in order to help them best cope with risk and exploit opportunity.

Drawing attention to the role of Government, even in the midst of what seems to be a process of deinstitutionalization, is also a reminder that the language of greater choice for individuals should not be used as a means to completely individualize responsibility for coping with the insecurities people now face. Ultimately, examination of the broader context suggests the genesis of retirement decisions is not simply, or not only, traceable back to individuals themselves. ${ }^{118}$ Equally, there are many individuals for whom outcomes will reflect an inability to adequately manage a pathway to retirement despite their best efforts. The role of the state in such situations should not be clouded, or in some way diluted, by the idea that individual responsibility automatically brings with it some notion of blame or fault when individuals nevertheless end up seeking security via the state. The importance of this point is underlined by Guillemard, who argues that:

we seem to be entering an era when security will be the central paradigm in social protection, as compared with...ideas about solidarity and coverage for risks that underlie our $20^{\text {th }}$-century welfare states... The major objective is, therefore, not to guarantee coverage for risks.... and provide stable jobs. Instead, it should make life-course trajectories, now individual and uncertain, secure. ${ }^{119}$

\footnotetext{
115 NAO (2004); OECD (2004).

116 Arthur (2003, p. 8).

117 Hirsch (2003, p. 27).

118 Vickerstaff et al. (2004).

119 Guillemard (2001, p. 6).
} 
It is submitted that Government has a clear responsibility here, and it is a responsibility that exists throughout the life course. Focusing upon the later part of the life course has, to some extent, masked this broader responsibility and its cumulative effect on the process of retirement. By emphasizing the broader responsibilities of Government, and examining the means by which that responsibility might best be fulfilled, this discussion may be seen as advocating the re-institutionlization of the life course.

These are significant issues. The fourth pillar movement and the drive for flexibility in the retirement process is an important programme, but it must continually be placed in this broader context and debate. An examination of current policy in the U.K. underlines the point. If flexibility and choice are to be harnessed in helping individuals to cope with risk and uncertainty, then the retirement process has to be set in the context of the entire life cycle. The involuntariness of early retirement in the over-50s may not be so much a consequence of a lack of flexibility and choice at one point in time, but a result of a lack of flexibility, or more properly of choice, throughout the life course as whole.

\section{References}

ACA (2003) 'Occupational pensions 2003 Pensions Reform: too little, too late?', Association of Consulting Actuaries.

Anon. (2004) 'Members continue to opt for an early retirement', Professional Pensions, 16th September 2004, p. 13.

Anon. (2005) 'Flexible working snubbed', Professional Pensions, 27th January 2005, p. 9.

Arthur, S. (2003) Money, Choice and Control: The Financial Circumstances of Early Retirement, Bristol: The Policy Press/Joseph Rowntree Foundation.

Bardasi, E. and Jenkins, S. (2002) Income in Later Life: Work History Matters, Bristol: The Policy Press/ Joseph Rowntree Foundation.

Beck, U. (1996) 'Risk and the Provident State', in S. Lash, B. Szerszynski and B. Wynne (eds) Risk, Environment and Modernity: Towards a New Ecology, London: Sage Publications.

Bender, K.A. (2004) The Well-Being of Retirees: Evidence Using Subjective Data, Working Paper 2004-24, Centre for Retirement Research at Boston College.

Boles, T. (2000) 'Finance flummoxes 75\% of the public', Money Management, 3rd August, 2000, p. 19.

Bone, J. and Mercer, S. (2000) Flexible Retirement, London: Employers Forum on Age.

Cocco, J. and Volpin, P. (2005) The Corporate Governance of Defined-Benefit Pension Plans: Evidence from the United Kingdom, CEPR Discussion Paper No. 4932, London: Centre for Economic Policy Research.

Compton-Edwards, M. (2001) Age Discrimination at Work, London: Chartered Institute of Personnel and Development.

Curry, C. and O'Connell, A. (2003) The Pensions Landscape, London: Pensions Policy Institute.

Disney, R., Emmerson, C. and Tanner, S. (1999) Partnership in Pensions: An Assessment, London: The Institute for Fiscal Studies.

Dunnewijk, B. (2002) 'Four pillars, four solutions: pension reform and insurance opportunities', The Geneva Papers on Risk and Insurance 27(4): 540-554.

DWP (2002) Simplicity, Security and Choice: Working and Saving for Retirement, Norwich: The Stationery Office.

DWP (2003) Simplicity, Security and Choice: Working and Saving for Retirement, Action on Occupational Pensions, Norwich: The Stationery Office.

DWP (2004) Simplicity, Security and Choice: Informed Choices for Working and Saving, Norwich: The Stationery Office.

Employer Task Force on Pensions (2004) Report to the Secretary of State for Work and Pensions, Ashby de la Zouche: Employer Task Force on Pensions. 
EPC (2000) Progress Report to the Ecofin Council on the Impact of Ageing Populations on Public Pension Systems, EPC/ECFIN/581/00-EN-Rev.1, Brussels: Economic Policy Committee.

EU Commission (1999) Towards a Europe for All Ages - Promoting Prosperity and Intergenerational Solidarity, COM(1999) 221 final, Brussels: Commission of the European Communities.

EU Commission (2002) Europe's Response to World Ageing: Promoting Economic and Social Progress in an Ageing World, Communication from the Commission to the Council and the European Parliament, $\operatorname{COM}(2002) 143$ final, Brussels: Commission of the European Communities.

FSA (2003) Towards a National Strategy for Financial Capability, London: Financial Services Authority.

GAD (2003) Government Actuary's Quinquennial Review of the National Insurance Fund, London: Government Actuary's Department.

Giddens, A. (1998) The Third Way: The Renewal of Social Democracy, Cambridge: Polity Press.

Grieve-Smith, J. (2004) 'How to solve the sickness benefit problem', Financial Times, 17 September, p. 19.

Guillemard, A.M. (1997) 'Re-writing social policy and changes within the life course organisation, a European perspective', Canadian Journal on Aging 16(3): 441-464.

Guillemard, A.M. (2001) The Advent of a Flexible Life Course and the Reconfiguration of Welfare, Denmark, Key Note Speech to Cost A 13 Conference on Social Policy, Marginalisation and Citizenship, 2-4 November 2001.

HL Select Committee on Economic Affairs (2003) Aspects of the Economics of an Ageing Population, Volume 1 - Report, London: TSO.

Hall, B. (2005) 'Benefit overhaul aims to put disadvantaged in work', Financial Times, 3rd February, p. 3.

Herbertsson, T. and Orszag, M. (2003) The Early Retirement Burden: Assessing the Costs of the Continued Prevalence of Early Retirement in OECD Countries, London: Watson Wyatt.

Hewitt Bacon \& Woodrow (2003) Analysis Benefits Research, No. 151, December 2003.

Hirsch, D. (2003) Crossroards after 50: Improving Choices in Work and Retirement, York: Joseph Rowntree Foundation.

Inland Revenue HM Treasury (2003) Simplifying the Taxation of Pensions: The Government's Proposals, December 2003. London, TSO.

Kessler, D. (1988) 'The four pillars of retirement', The Geneva Papers on Risk and Insurance 13(4): 342-349.

Malik, S. (2005) 'A very British sickness', New Statesman, 10 January, pp. 27-29.

Meadows, P. (1999) The Flexible Labour Market: Implications for Pension Provision, London: National Association of Pension Funds.

Meadows, P. (2003) Retirement Ages in the U.K.: A Review of the Literature, DTI Employment Relations Research Series No. 18. London: Department of Trade and Industry.

Mercer Oliver Wyman (2001) The Future Regulation of U.K. Savings and Investment: Targeting the Savings Gap, London: Oliver Wyman \& Company.

NAO (2004) Welfare to Work: Tackling the Barriers to the Employment of Older People, Report by the Comptroller and Auditor General of the National Audit Office, London: The Stationery Office.

NCC (2003) Consumer Facts, May 2003 (PD 37/03), London: National Consumer Council.

OECD (2004) Ageing and Employment Policies: United Kingdom, Paris: Organisation for Economic Co-operation and Development.

Pensions Commission (2004) Pensions: Challenges and Choices, The First Report of the Pensions Commission, Norwich: TSO.

Phillipson, C. (1999) 'The social construction of retirement: perspectives from critical theory and political economy', in M. Minkler and C.L. Estes (eds) Critical Gerontology: Perspectives from Political and Moral Economy, Amityville, US: Baywood Publishing Company Inc.

Phillipson, C. (2002) Transitions from Work to Retirement: Developing a New Social Contract, Bristol: The Policy Press/Joseph Rowntree Foundation.

PIU (2000) Winning the Generation Game: Improving Opportunities for People Aged 50-65 in Work and Community Activity, London: Performance and Innovation Unit, Cabinet Office.

Pomerantz, O. and Weale, M. (2005) 'Are we saving enough? The macroeconomics of the savings gap', National Institute Economic Review 191(January): 79-93.

Reday-Mulvey, G. (2002) 'Main achievements of the program', The Four Pillars (31): 2-7.

Rowlingson, K. (2000) Fate, Hope and Insecurity: Future Orientation and Forward Planning, Bristol: Joseph Rowntree Foundation. 
Skypala, P. (2003) 'FSA 'is failing to spend on consumer education', Financial Times, 11th March, p. 6.

Targett, S (2002) 'Managing funds to the letter', Financial Times, FTfm, p. 6.

Taylor, P. (2002) New Policies for Older Workers, Bristol: The Policy Press/Joseph Rowntree Foundation. Taylor, P. and Walker, A. (2003) 'Age discrimination in the labour market and policy responses: the situation in the United Kingdom', The Geneva Papers on Risk and Insurance 28(4): 612-624.

Taylor-Gooby, P. (2000) 'Risk and welfare', in P. Taylor-Gooby (ed) Risk, Trust and Welfare, London: Palgrave Macmillan.

The Geneva Association (2002) 'The Four Pillars - Research Pogramme on Social Security, Insurance, Savings and Employment', The Four Pillars 31, August 2002.

Turner, D. (2004) 'Business wins battle on retirement age', Financial Times, 15th December, p. 2.

Vickerstaff, S., Baldock, J., Cox, J. and Keen, L. (2004) Happy Retirement? The Impact of Employers' Policies and Practice on the Process of Retirement, Bristol: The Policy Press/Joseph Rowntree Foundation.

Vickerstaff, S., Cox, J. and Keen, L. (2003) 'Employers and the management of retirement', Social Policy \& Administration 37(3): 271-287.

Watson, W. (2005) 'Pension reform in Japan and Germany: time to panic?' Watson Wyatt Insider 15(1): $13-19$.

\begin{abstract}
About the Author
Patrick John Ring is a Senior Lecturer in Financial Services of Glasgow Caledonian University. His research interests include pensions and the regulation of financial services.
\end{abstract}

